\title{
Parathyroid Hormone Induces Interleukin-6 Gene Expression in Bone Stromal Cells of Young Rats
}

\author{
Shuichi CHIBA ${ }^{1,2)}$, Masako UN-NO ${ }^{3)}$, Robert M. NEER ${ }^{1)}$, Kosuke OKADA ${ }^{2)}$, Gino V. SEGRE ${ }^{1)}$ and Kaechoong LEE ${ }^{1)}$ \\ ${ }^{1)}$ Endocrine Unit, Massachusetts General Hospital, Harvard Medical School, Fruit Street, Boston, MA 02114, U.S.A. ${ }^{2)}$ Department of \\ Veterinary Pathology, Faculty of Agriculture, Iwate University, 3-18-8 Ueda, Morioka, Iwate 020-8550 and ${ }^{3)}$ Safety Assessment \\ Laboratory, Chugai Pharmaceutical Co., Ltd., 1-135 Komakado, Gotemba, Shizuoka 412-8513, Japan
}

(Received 15 January 2002/Accepted 20 March 2002)

ABSTRACT. To test the hypothesis that parathyroid hormone (PTH) regulates interleukin-6 (IL-6) expression locally in bone, the expression of IL-6 mRNA was examined by in situ hybridization after a subcutaneous injection of human PTH [1-84] $(225 \mu \mathrm{g} / \mathrm{kg})$ in 4-week old rats. Whereas IL-6 mRNA was not detected at the basal status, it was transiently detected in a subpopulation of stromal cells in the intertrabecular region of the metaphyses from $1 / 2$ to $1 \mathrm{hr}$ after PTH injection. Contrastingly, IL- 6 transcripts were not detected in other cell populations at any time points examined. Since IL-6 is a known activator of osteoclasts, these results are consistent with the hypothesis that PTH stimulates the local IL-6 synthesis in stromal cells to indirectly activate osteoclasts.

KEY WORDS: interleukin-6, parathyroid hormone, stromal cell.

It has been postulated for some time that parathyroid hormone (PTH) stimulates bone resorption by indirectly activating osteoclasts $[12,14]$. Consistent with this hypothesis, transcripts for the PTH/PTH related protein (PTHrP) receptor $(\mathrm{PTH} / \mathrm{PTHrPR})$ are not found in osteoclasts, but are expressed in osteoblasts and in a subpopulation of intertrabecular stromal cells [8]. In addition, when 4-week old rats are given a bolus administration of PTH, c-fos mRNA expression is observed in the same cells as those expressing PTH/PTHrPR mRNA at 15-30 min after the injection. Furthermore, after c-fos mRNA expression disappears in these initial responders, c-fos transcripts are expressed in osteoclasts at a later time point ( $2 \mathrm{hr}$ ), further supporting the hypothesis that PTH-activation of osteoclasts is indirect [8].

Interleukin-6 (IL-6) has been thought to be a likely candidate to mediate indirect actions of PTH on osteoclasts. IL-6 gene expression in both clonal osteoblastic cell lines and primary osteoblasts is stimulated by $\mathrm{PTH}$ in vitro $[3,4,11]$, and PTH increases circulating levels of IL-6 [6] as well as IL-6 expression in bone in vivo [13]. In addition, PTH-activation of osteoclasts is partially blocked by anti-IL-6 receptor antibody in vitro [5], and PTH's bone resorbing activity in vivo also dramatically decreases in the absence or inactivation of IL-6 in mice [6]. Increase in circulating levels of IL-6 alone, however, does not increase the number of osteoclasts in mice with an IL-6 transgene [7]. Moreover, using a retrovirally mediated IL-6 overexpression system, Sanduh et al. have shown that local production of IL-6 in bone is required to increase the number of osteoclasts [15]. Although evidence supports the hypothesis that local production of IL-6 stimulated by PTH mediates PTH's osteoclast activation (at least partially), the identity of cells that manifest an IL-6 response to PTH has not been determined. To test the hypothesis that PTH regulates IL-6 expression locally in bone, and to identify cells that express IL-6 in response to $\mathrm{PTH}$, we examined IL-6 mRNA expression in bone of young rats before and after a single subcutaneous injection of PTH.

Four-week old male Sprague-Dawley rats were purchased from Charles River Co., Inc. (Wilmington, MA) and maintained according to the NIH Guide for the Care and Use of Laboratory Animals. Before, and 0.25, 0.5, 1, 2, 4, $6 \mathrm{hr}$ after a single subcutaneous injection of recombinant human PTH[1-84] (Chugai Pharmaceutical Co., Ltd., Tokyo, Japan) at $225 \mu \mathrm{g} / \mathrm{kg}$ body weight, rats were anesthetized with ether, and then were perfused with freshly prepared $4 \%$ paraformaldehyde (PFA)/phosphate-buffered saline (PBS) (pH 7.4). Femurs were removed, fixed in 4\% PFA/PBS at $4^{\circ} \mathrm{C}$ overnight, and then decalcified in $20 \%$ EDTA/ $10 \%$ formalin for 2 weeks. Frozen $(8 \mu \mathrm{m})$ sections were prepared by standard procedures and collected on precoated slide glass (Super Frost Plus, Fisher Scientific Int'1, Hampton, NH).

Complementary DNA (cDNA) encoding mouse IL-6 was purchased from American Type Culture Collection (Manassas, VA). Sense and antisense ${ }^{35} \mathrm{~S}$-RNAs were synthesized from the linearized plasmids using the Gemini Transcription Kit (Promega, Madison, WI) and ${ }^{35}$ S-UTP $(1367.0 \mathrm{Ci} /$ mmol; New England Nuclear, Boston, MA).

Sections were post-fixed with freshly prepared $4 \% \mathrm{PFA} /$ PBS for $15 \mathrm{~min}$. After washing with PBS, sections were digested with $1 \mu \mathrm{g} / \mathrm{m} l$ proteinase $\mathrm{K}\left(37^{\circ} \mathrm{C}, 15 \mathrm{~min}\right)$ in $\mathrm{PBS}$, and again treated with $4 \%$ PFA/PBS (10 min) to inactivate proteinase K. Sections were sequentially washed with PBS, treated with $0.2 \mathrm{~N} \mathrm{HCl}$ (10 min), again washed with PBS, acetylated with $0.25 \%$ acetic anhydride in the presence of triethanolamine $(0.1 \mathrm{M}, 10 \mathrm{~min})$, dehydrated with increasing concentrations of ethanol, and air-dried. Hybridizations with ${ }^{35} \mathrm{~S}$-labeled cRNAs $\left(5 \times 10^{7} \mathrm{cpm} / \mathrm{m} l\right)$ were performed in a humidified chamber in a solution containing $50 \%$ formamide, $10 \%$ dextran sulfate, $1 \times$ Denhardt's solution, 600 $\mathrm{mM} \mathrm{NaCl}, 10 \mathrm{mM}$ DTT, $0.25 \%$ SDS, and $150 \mu \mathrm{g} / \mathrm{m} l$ tRNA $\left(18 \mathrm{hr}, 55^{\circ} \mathrm{C}\right)$. After hybridization, sections were sequen- 

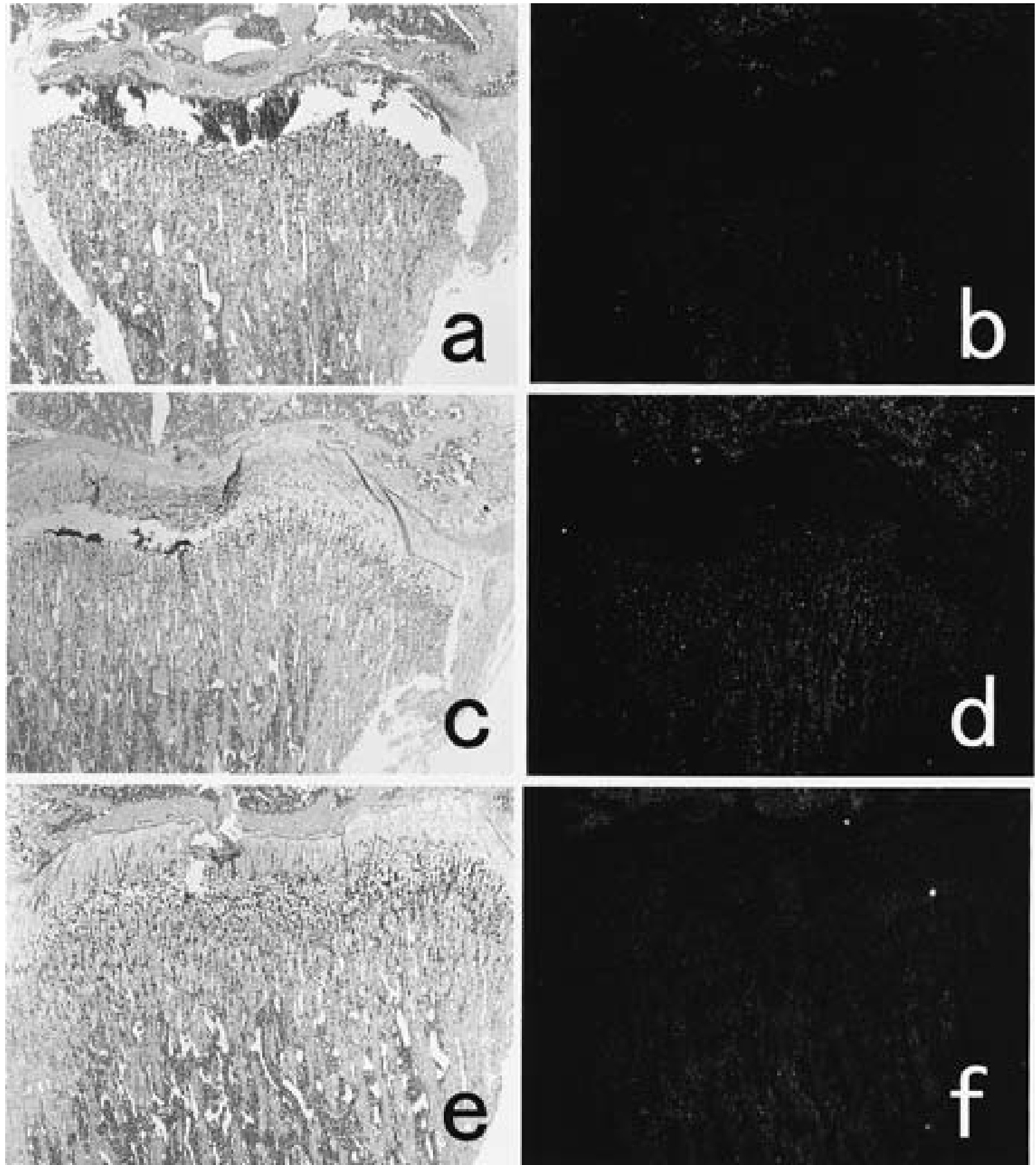

Fig. 1. IL-6 mRNA expression in the femur of 4-week old rats before and after a single injection of recombinant human PTH[1-84]. Both bright-field (a, c, e) and dark-field (b, d, f) views of sections hybridized with ${ }^{35}$ S-labeled IL-6 cRNA are shown. Whereas IL-6 mRNA is not detectable at the basal status $(\mathrm{a}, \mathrm{b})$, its expression becomes evident in cells scattered in the metaphyseal region and the secondary ossification center by $1 \mathrm{hr}(\mathrm{c}, \mathrm{d})$. By $2 \mathrm{hr}$, IL-6 mRNA expression returns to the basal level and not detectable any longer $(\mathrm{e}, \mathrm{f})(\times 40)$.

tially washed briefly with $5 \times \mathrm{SSC}$ at $50^{\circ} \mathrm{C}, 50 \%$ formamide/ $2 \times \mathrm{SSC}\left(50^{\circ} \mathrm{C}\right), 10 \mathrm{mM}$ Tris- $\mathrm{HCl}(\mathrm{pH} 7.6)-500 \mathrm{mM} \mathrm{NaCl}-1$ mM EDTA (TNE), and then treated with $10 \mu \mathrm{g} / \mathrm{m} l$ RNase A in $\mathrm{TNE}\left(37^{\circ} \mathrm{C}, 30 \mathrm{~min}\right)$. After washing with TNE, sections were incubated once with $2 \mathrm{x} \operatorname{SSC}\left(50^{\circ} \mathrm{C}, 20 \mathrm{~min}\right)$, twice with $0.2 x \operatorname{SSC}\left(50^{\circ} \mathrm{C}, 20 \mathrm{~min}\right)$, dehydrated with increasing concentrations of ethanol, and air-dried. Slides were placed on X-ray films (HyperFilm $\beta$-max, Amersham, Arlington 

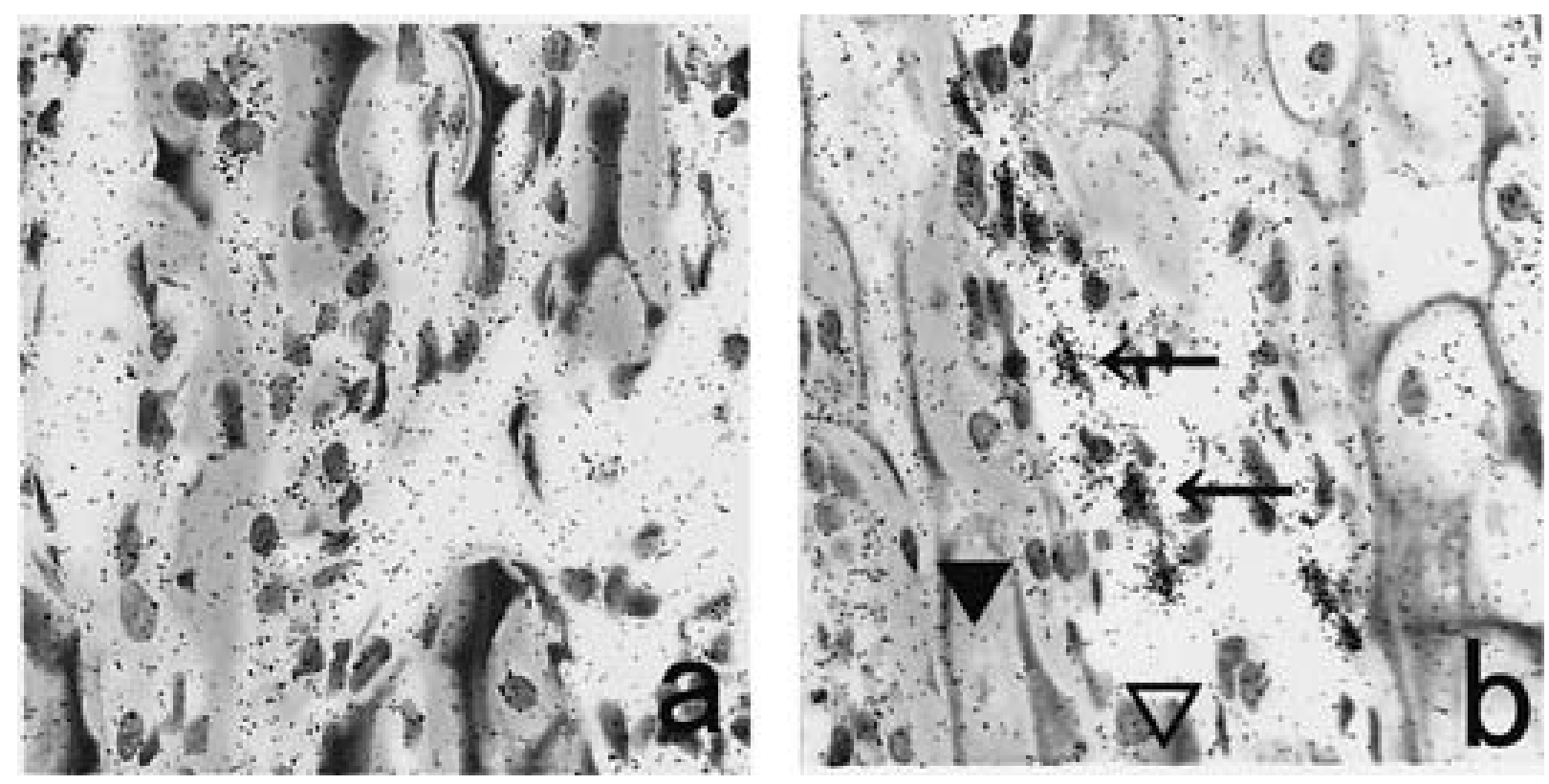

Fig. 2. IL-6 mRNA expression in stromal cells in the femur $1 \mathrm{hr}$ after bolus injections of recombinant human PTH[1-84]. Prior to PTH injection, IL-6 mRNA expression is not detectable (a). One hr after PTH injection (b), IL-6 mRNA is highly expressed in some stromal cells located in the intertrabecular region (a few examples of positive cells are indicated by arrows), whereas IL6 mRNA is not detectable in osteoblasts (closed arrowhead), osteoclasts (open arrowhead), or the majority of stromal cells $(\times 400)$.

Heights, IL), and the autoradiographs were obtained after overnight exposure. Slides were dipped into photo emulsion (NTB-2, Eastman Kodak, New Haven, CT), stored at $4^{\circ} \mathrm{C}$ for the period estimated from the intensity of expression on the X-ray films. After development, sections were counterstained with hematoxylin and eosin.

A single subcutaneous injection of PTH induced transient IL-6 mRNA expression in bones of 4-week old rats. As shown in Figs. 1 and 2, IL-6 mRNA expression in bone cells was not detectable in the femur at the basal status. Whereas IL-6 mRNA expression was not detectable at $1 / 4 \mathrm{hr}$ after the PTH injection, it was detectable in a few stromal cells in the metaphyses by $1 / 2 \mathrm{hr}$ (data not shown). IL-6 mRNA expression in stromal cells reached its peak by $1 \mathrm{hr}$, and returned to the basal level by $2 \mathrm{hr}$ (Figs. 1 and 2). At $1 \mathrm{hr}$, cells expressing IL-6 mRNA were distributed in a scattered pattern in the intertrabecular region of the methaphyses (Fig. 2b); the majority of stromal cells, however, did not express the transcripts. In contrast, IL-6 mRNA expression was not detectable in either osteoblasts or osteoclasts (Fig. 2b) at any of the time points examined ( 0 to $6 \mathrm{hr}$ ).

In this study, we have shown that a single administration of PTH transiently induces IL-6 mRNA in stromal cells in the bone of 4-week old rats. The time course of PTHinduced IL-6 mRNA expression in vivo is similar to the previously reported in vitro data with clonal osteoblastic cell lines and primary osteoblasts $[3,4,11]$, and exhibits a typical "immediate early gene response" pattern [16], i.e. transient and brief expression with its peak ranging from $1 / 4$ to
$1 \mathrm{hr}$. IL-6 mRNA expression in stromal cells reaches its peak by $1 \mathrm{hr}$ and returns to the basal level by $2 \mathrm{hr}$ after PTH administration. The similarity of the time course of PTHinduced IL-6 mRNA expression between previous in vitro studies with osteoblastic cells $[4,11]$ and our in situ hybridization data are consistent with the notion that stromal cells that express IL- 6 transcripts in response to PTH in vivo belong to the osteoblast lineage. Moreover, since IL-6 mRNA is not detected in mature osteoblasts at any of the time points ( 0 to $6 \mathrm{hr}$ ) examined after PTH injection, it is speculated that osteoblast precursors are the principal bone cells that manifest an IL-6 response to PTH in vivo, although we do not exclude the possibility that these IL-6 expressing cells belong to other cell lineage such as the osteoclast lineage.

The pattern of mRNA localization of IL-6 after PTH treatment observed in this study differs from the pattern of IL-6 protein localization previously reported by Liang and colleagues [10]. According to them, IL-6 protein was detected in osteoblasts, osteocytes, megakaryocytes and scattertered islands of hemopoietic cells $1 \mathrm{hr}$ after PTH injection. Since immunolocalization does not necessarily differentiate the site of synthesis from the site of accumulation, cells positive for IL-6 protein may well be due to IL-6 accumulation on or in target, rather than IL-6 producing, cells. Such a discordant distribution between sites of ligand synthesis and accumulation of immunodetectable protein has been previously reported for other growth factors, including transforming growth factor $\beta 1$ [1], nerve growth 
factor [2], insulin-like growth factors [17], and PTHrP [9]. Also, the difference in the treatment protocols between our study (single injection) and theirs (daily injection for 5 days) may relate to this discrepancy.

We do not know, however, whether or not the PTHinduction of IL-6 gene expression in stromal cells is direct or indirect. Although the pattern of IL-6 mRNA expression at its peak resembles that of PTH/PTHrPR mRNA expression in stromal cells [8], it is possible that PTH induces IL6 mRNA expression in a subpopulation of stromal cells indirectly. If that is the case, other cytokines or cell-surface factors also may be involved in the PTH-induction of IL-6 mRNA expression in stromal cells. Irrespective of whether PTH-induction of IL-6 mRNA is direct or indirect, our data clearly demonstrate that IL- 6 expression is induced by PTH in bone stromal cells in vivo, suggesting that IL- 6 produced by osteoblast precursors play a role(s) in mediating PTH's indirect activation of osteoclasts.

\section{REFERENCES}

1. Akhurst, R.J., Lehnert, S.A., Gatherer, D. and Duffie, E. 1990. Ann. New York Acad. Sci. 593: 259-271.

2. Davies, A.M., Bandtlow, C., Heumann, R., Korsching, S., Rohrer, H. and Thoenen, H. 1987. Nature (Lond.) 326: 353358.

3. Feyen, J.H.M., Elford, P., Di Padpva, F.E. and Trechsel, U. 1989. J. Bone Miner. Res. 4: 633-638.

4. Greenfield, E.M., Gornik, S., Horowitz, M.C., Donahue, H.J. and Shaw, S.M. 1993. J. Bone Miner. Res. 8: 1163-1171.

5. Greenfield, E.M., Shaw, S.M., Gornik, S.A. and Banks, M.A. 1995. J. Clin. Invest. 96: 1238-1244.

6. Grey, A., Mitnik, M.-A., Masiukiewicz, U., Sun, B.-H., Rudikoff, S., Jilka, R.L., Monolagas, S.C. and Insogna, K.A. 1999. Endocrinology 140: 4683-4690.

7. Kitamura, H., Kawata, H., Takahashi, F., Higuchi, Y., Furuichi, T. and Ohkawa, H. 1995. Am. J. Pathol. 147: 1682-1692.

8. Lee, K., Deeds, J.D., Chiba, S., Un-No, M., Bond, A.T. and Segre, G.V. 1994. Endocrinology 134: 441-450.

9. Lee, K., Lanske, B., Karaplis, A.C., Deeds, J.D., Kohno, H., Nissenson, R., Kronenberg, H.M. and Segre, G.V. 1996. Endocrinology 137: 5109-5118.

10. Liang, J.D., Hock, J.M., Sandusky, G.E., Santerre, R.F. and Onyia, J.E. 1999. Calcif. Tissue Int. 65: 369-373.

11. Lowik, C.W.G.M., van der Pluijm, G., Bloys, H., Hoekman, K., Bijvoet, O.L.M., Aarden, L.A. and Papapoulos, S.E. 1989. Biochem. Biophys. Res. Commun. 162: 1546-1552.

12. McSheehy, P.M.J. and Chambers, T.J. 1986. Endocrinology 118: 824-828.

13. Pollock, J.H., Blaha, M.J., Lavish, S.A., Stevenson, S. and Greenfield, E.M. 1996. J. Bone Miner. Res. 11: 754-759.

14. Rodan, G.A. and Martin, T.J. 1981. Calcif. Tissue Int. 33: 349352.

15. Sandhu, J.S., Gorczynski, R.M., Waddell, J., Nguyen, H., Squires, J., Waddell, J., Bonynton, E.L. and Hozumi, N. 1999. Bone 24: 217-227.

16. Sharp, F.R. and Sagar, S.M. 1994. Neurotoxicology 15: 51-60.

17. Wang, E., Wang, J., Chin, E., Zhou, J. and Bondy, C.A. 1995. Endocrinology 136: 2741-2751. 